\title{
The results of evaluation of the collection of cocksfoot in the Central Chernozem zone
}

\author{
Natalia Malysheva ${ }^{1, *}$, Elena Gubanova ${ }^{2}$, Nadezhda Isaeva $^{2}$, Alexander Gubanov ${ }^{2}$ \\ ${ }^{1}$ N.I. Vavilov All-Russian Institute of Plant Genetic Resources, 42, 44, Bolshaya Morskaya St., St. \\ Petersburg, 190000, Russia \\ ${ }^{2}$ Ekaterininskaya Research Station, branch of the N. I. Vavilov All-Russian Institute of Plant Genetic \\ Resources (VIR), Nikiforovsky District, Tambov Province, Russian Federation
}

\begin{abstract}
Cocksfoot is one of the earliest, highly nutritious valuable forage crops, which is widely used in agricultural production. It is relevant in developing varieties adapted to the environmental stress factors that have productive longevity, increased seed and fodder productivity. The paper presents the results of wild cocksfoot accessions conducted on Ekaterininskaya RS in 2017-2019. No accessions of cocksfoot were identified that consistently exceeded the standard grade for all three years of study. Accessions collected in the North Caucasus and Tajikistan and introduced from the Mediterranean region performed well in the first year of life, but by the third year of the life, they significantly reduced all characteristics. The accessions of cocksfoot from the Central Region of the European part of the RF and from the mountainous regions of the Southern Urals are of the greatest interest for breeding in the Central Chernozem zone.
\end{abstract}

\section{Introduction}

Cocksfoot is a friable bunch perennial winter type cereal widely distributed in the forest and forest-steppe zone of Eurasia. The species has a wide range of variability, occupying a vast territory with different climatic conditions. Cocksfoot is one of the earliest, highly nutritious valuable forage crops, which is widely used in agricultural production. The main priority of breeding programs is the creation of new high-yielding varieties with a wide adaptive potential in various environmental conditions [1]. Among wild-growing accessions, it is possible to find superior zoned varieties according to economically valuable characteristics [2].

The VIR collection includes about 1200 wild and cultural accessions, collected during expeditions and received from abroad. The collection is constantly being updated, and newly received accessions are being studied at VIR experimental stations. The accessions distinguished by economically valuable characteristics are involved in the selection process to create new promising varieties.

\footnotetext{
* Corresponding author: nataliem1@yandex.ru
} 
The Ekaterininskaya research station of VIR, where the collection of cocksfoot was studied, is located in the Nikiforovsky district of the Tambov region in the north-eastern part of the Central Chernozem district.

The climate in the Tambov region is moderately continental with small deviations from the average annual norms [3], with long summers and relatively cold winters with a stable snow cover. The average temperature of the warmest month of July is $+19.8{ }^{\circ} \mathrm{C}$, and the coldest month of January is $-10.9{ }^{\circ} \mathrm{C}$. The maximum air temperature in the summer months in some years can reach $+41^{\circ} \mathrm{C}$. The minimum air temperature in the winter months drops to $-37-41{ }^{\circ} \mathrm{C}$. The average annual precipitation is $510-560 \mathrm{~mm}$, in the warm period $-300-350$ $\mathrm{mm}$ [4]. There is sufficient moisture from May to July, insufficient in August and excessive in September (hydrothermal coefficient is 0.8-1.4) with fluctuations over the years [5]. In summer, there are frequent dry winds; there are long droughts every 10-12 years [6]. The soils on the territory of the research station are leached chernozems.

The selection of highly productive accessions of cocksfoot from the presented set makes it possible to offer material for the creation of new varieties in the Central Chernozem zone with high indicators of feed productivity and seed yield.

\section{Material and methods}

The study included 25 accessions of cocksfoot: the Torpeda variety selected by the Penza Research Institute, and newly received wild accessions collected by VIR expeditions in the Central Region of Russia, the Urals, the North Caucasus, Ukraine and Tajikistan and the ones received by discharge from France and Portugal are among the latest acquisitions (Table).

The sowing of cocksfoot accessions was carried out in 2016. The study lasted for three years (2017-2019). The experiment was based on a modified VIR method [7].

Variety Morshanskaya 143, zoned in the Central Chernozem zone, was taken as a standard variety for comparison. The study of the cocksfoot collection was carried out according to the following economically valuable characteristics: the duration of the growing season, the height of plants on the $20^{\text {th }}$ day from the beginning of spring regrowth, the height of plants before mowing, the height of plants during flowering, the yield of green mass, seed productivity and foliage. The cut was carried out in the phase of entering the tube-the beginning of earing.

Table 1. List of wild and cultural accessions of cocksfoot (Dactylis glomerata L.).

\begin{tabular}{|c|c|c|}
\hline $\begin{array}{c}\text { Number of VIR } \\
\text { catalog }\end{array}$ & Name & Origin \\
\hline k-24412 & Morshanskaya 143 & Russia, Tambov reg. \\
\hline k-51644 & Torpeda & Russia, Penza reg. \\
\hline i-148538 & Wild & Russia, Ryazan reg. \\
\hline i-148548 & Wild & Russia, Tula reg. \\
\hline i-148553 & Wild & Russia, Tula reg. \\
\hline i-148555 & Wild & Russia, Tula reg. \\
\hline i-149345 & Wild & Russia, Vladimir reg. \\
\hline i-149346 & Wild & Russia, Vladimir reg. \\
\hline i-149362 & Wild & Russia, rep. Mordovia \\
\hline i-149421 & Wild & Russia, rep. Bashkortostan \\
\hline k-51637 & Wild & Russia, rep. Bashkortostan \\
\hline k-51854 & Wild & Russia, rep. Bashkortostan \\
\hline k-51855 & Wild & Russia, rep. Karachay-Cherkessia \\
\hline k-52340 & Wild & Russia, rep. Karachay-Cherkessia \\
\hline K-52341 & Wild & Russia, rep. Karachay-Cherkessia \\
\hline k-52343 & Wild & \\
\hline
\end{tabular}




\begin{tabular}{|c|c|c|}
\hline k-52344 & Wild & Russia, rep. Adygea \\
\hline K-52345 & Wild & Russia, Adygea rep. \\
\hline k-52346 & Wild & Russia, Adygea rep. \\
\hline i-149849 & Wild & Russia, Stavropol reg. \\
\hline k-51859 & Wild & Ukraine \\
\hline k-51012 & Wild & Tajikistan \\
\hline k-51013 & Wild & Tajikistan \\
\hline k-51014 & Wild & France \\
\hline k-51015 & Wild & Portugal \\
\hline k-46979 & Wild & Russia, Tambov reg. \\
\hline
\end{tabular}

Statistical data processing was performed using the Statistica 12.0 software package and included the calculation of the main variation parameters (mean, mean error) and factorial (two-way) ANOVA.

During the three years of studying the cocksfoot collection, in some years the temperature regime significantly differed from the average long-term readings. In January and February, in all the years of the study, the average air temperature was 2-5 degrees higher than the longterm average; the temperature in the autumn months of 2016 and from May to October 2017 was at the level of the long-term average. December 2016 and March 2017 were 2-3 degrees colder than normal. May and June 2017 were $2-3{ }^{\circ} \mathrm{C}$ colder than the long-term average values.

The amount of precipitation during the growing season in the years of study varied from year to year. The annual precipitation in 2017 and 2018 was below normal (404 and $445 \mathrm{~mm}$, respectively). The lack of moisture was especially noticeable in June during all the years of study and in May 2017.

\section{Results and discussion}

Vegetation period. In 2017, all accessions were characterized by greater precocity compared to the standard; the most precocious accessions were k-51637 (87 days) and k-51855 (88 days) from republic Bashkortostan, the duration of the standard vegetation period - 99 days. In 2018, the duration of the vegetation period of eight accessions was at the standard level (76 days), the rest had even longer duration. In 2019, vegetation period of the standard was 81 days, 6 accessions had the same duration, the rest were later maturing.

The long growing season of cocksfoot in 2017 comparing to other years was probably due to relatively low air temperatures in May and early June. On May 29, the temperature was only $1.5^{\circ} \mathrm{C}$.

Height on the $20^{\text {th }}$ day after spring regrowth. Standard variety Morshanskaya 143 has been surpassed by 11 accessions on the $20^{\text {th }}$ day after spring regrowth in 2017 . The tallest among them were wild accessions i-149849 from the Stavropol region, k-52343 from republic Karachayevo-Cherkessia and k-52345 from republic Adygea. Six accessions were at the standard level. There were no accessions exceeding standard variety in 2018, but two wild accessions were at the standard level: i-149421 from republic Mordovia and i-148555 from Tula region. Only one accession reached the standard level in 2019 - k-52345 from republic Adygea, marked in 2017.

The height before the $\mathbf{1}^{\text {st }}$ cut. Seven wild accessions were distinguished by height before the $1^{\text {st }}$ cutting in 2017 . Three wild accessions among them were higher than one meter: $\mathrm{i}-$ 149362 from Nizhny Novgorod region $(106 \mathrm{~cm})$, i-148555 from Tula Region $(102 \mathrm{~cm})$, k51855 from republic Bashkortostan $(101 \mathrm{~cm})$. There were ten accessions that reached the standard level, $92 \mathrm{~cm}$. Only one wild accession k-51012 from Tajikistan $(91 \mathrm{~cm})$ was at the standard level in 2018, the standard is $93 \mathrm{~cm}$. In 2019 no accessions surpassed the standard level, and six accessions reached the standard level. Highest of them were the variety Torpeda 
k-51644 $(83 \mathrm{~cm})$ and wild accession i-149421 from republic Mordovia $(82 \mathrm{~cm})$, the height of the standard is $80 \mathrm{~cm}$.

Height in the mass flowering phase. In the phase of mass flowering in 2017, 7 accessions exceeded the standard in height, of which the most significantly i-149362 (125 $\mathrm{cm})$, i-148555 from republic Adygea, k-51854 and k-51855 (120 cm each). Seven accessions reached the level of the standard $-110 \mathrm{~cm}$. In 2018, two accessions k-51012 and k-46979 $(107 \mathrm{~cm})$ exceeded the standard in height, 5 accessions reached the level of the standard (103 $\mathrm{cm})$. Only one accession stood out in 2019 - k-51644 $(83 \mathrm{~cm})$, six accessions had height at the standard level, of which i-149421 surpassed almost confidently $(82 \mathrm{~cm})$. The height of the standard variety was $80 \mathrm{~cm}$.

Foliage. In 2017, eight accessions stood out by foliage (especially k-51015 from Portugal $-47 \%$ ) and four accessions were equal to the standard. The foliage of standard variety Morshanskaya 143 was $25 \%$ in 2017 . The collection of cocksfoot was distinguished by high foliage in 2018: Eleven accessions exceeded the standard and seven accessions were equal to it. The leafiest accessions are k-51855 from Bashkortostan republic (41\%), k-51014 from France (40\%) and k-51015 from Portugal (39\%) with foliage of the standard variety $22 \%$. The foliage was also high in 2019: Seven accessions were above and seven accessions were at the standard level. Especially stood out accessions i-149345 from Vladimir region (67 \%), k-52341 from republic Karachay-Cherkessia (63\%) and K-51012 from Tajikistan (60\%). The standard foliage was $38 \%$.

Yield of green mass. Wild accessions k-52343 $\left(1.85 \mathrm{~kg} / \mathrm{m}^{2}\right), \mathrm{k}-52341\left(1.65 \mathrm{~kg} / \mathrm{m}^{2}\right)$ from republic Karachayevo-Cherkessia and k-51637 from republic Bashkortostan $\left(1.65 \mathrm{~kg} / \mathrm{m}^{2}\right)$ significantly exceeded the standard in 2017; the yield of eight accessions was at the standard level $-1.40 \mathrm{~kg} / \mathrm{m}^{2}$ (Figure). There were four wild accessions $\mathrm{k}-51637$ from the republic Bashkortostan $\left(1.25 \mathrm{~kg} / \mathrm{m}^{2}\right), \mathrm{k}-51012$ and k-51013 from Tajikistan, i-0149346 from the Vladimir region $\left(1.00 \mathrm{~kg} / \mathrm{m}^{2}\right)$ exceeding the standard, five accessions were unreliably different in $2018\left(1.35 \mathrm{~kg} / \mathrm{m}^{2}\right)$. Only one accession k-51637 from republic Bashkortostan exceed $\left(1.10 \mathrm{~kg} / \mathrm{m}^{2}\right)$ standard level and four accessions were at the standard level -1.45 $\mathrm{kg} / \mathrm{m}^{2}$ in 2019 .

The study of perennial fodder cereals in Tambov region at the Ekaterininskaya research station VIR was carried out in the 70s of the 20th century [8], including the cocksfoot. It was noted, that the yield of the green mass of the cocksfoot was the highest in the third year of life, reaching $387 \mathrm{c} /$ ha in individual accessions, whereas, in the second and fourth years of life, the yield was significantly lower: $82 \mathrm{c} / \mathrm{ha}$.

The most part of the collection of cocksfoot, studied in 2017-2019, had highest yield of green mass in the second year of the life (Figure).

Seed yield. In 2017, accessions from collection were distinguished by a high seed yield: twelve accessions exceeded the standard variety in seed productivity and ten were equal to it (Figure). Accessions i-148548 from Tula region $\left(55 \mathrm{~g} / \mathrm{m}^{2}\right)$, i-149362 from Nizhny Novgorod region $\left(48 \mathrm{~g} / \mathrm{m}^{2}\right)$ and $\mathrm{k}-51855$ from republic Bashkortostan $\left(46 \mathrm{~g} / \mathrm{m}^{2}\right)$ stood out in 2017 ; seed productivity of standard-was only $23 \mathrm{~g} / \mathrm{m}^{2}$. None of accessions exceeded the standard in 2018, five accessions were equal to the standard; among them were i-149362 from Nizhny Novgorod region $\left(39 \mathrm{~g} / \mathrm{m}^{2}\right)$ and k-51012 from Tajikistan $\left(37 \mathrm{~g} / \mathrm{m}^{2}\right)$ and standard yield was $36 \mathrm{~g} / \mathrm{m}^{2}$. In 2019 stood out the accession $\mathrm{i}-148548$ from Tula region $\left(62 \mathrm{~g} / \mathrm{m}^{2}\right)$; five accessions had seed productivity at the standard level $\left(42 \mathrm{~g} / \mathrm{m}^{2}\right)$ in 2019. 

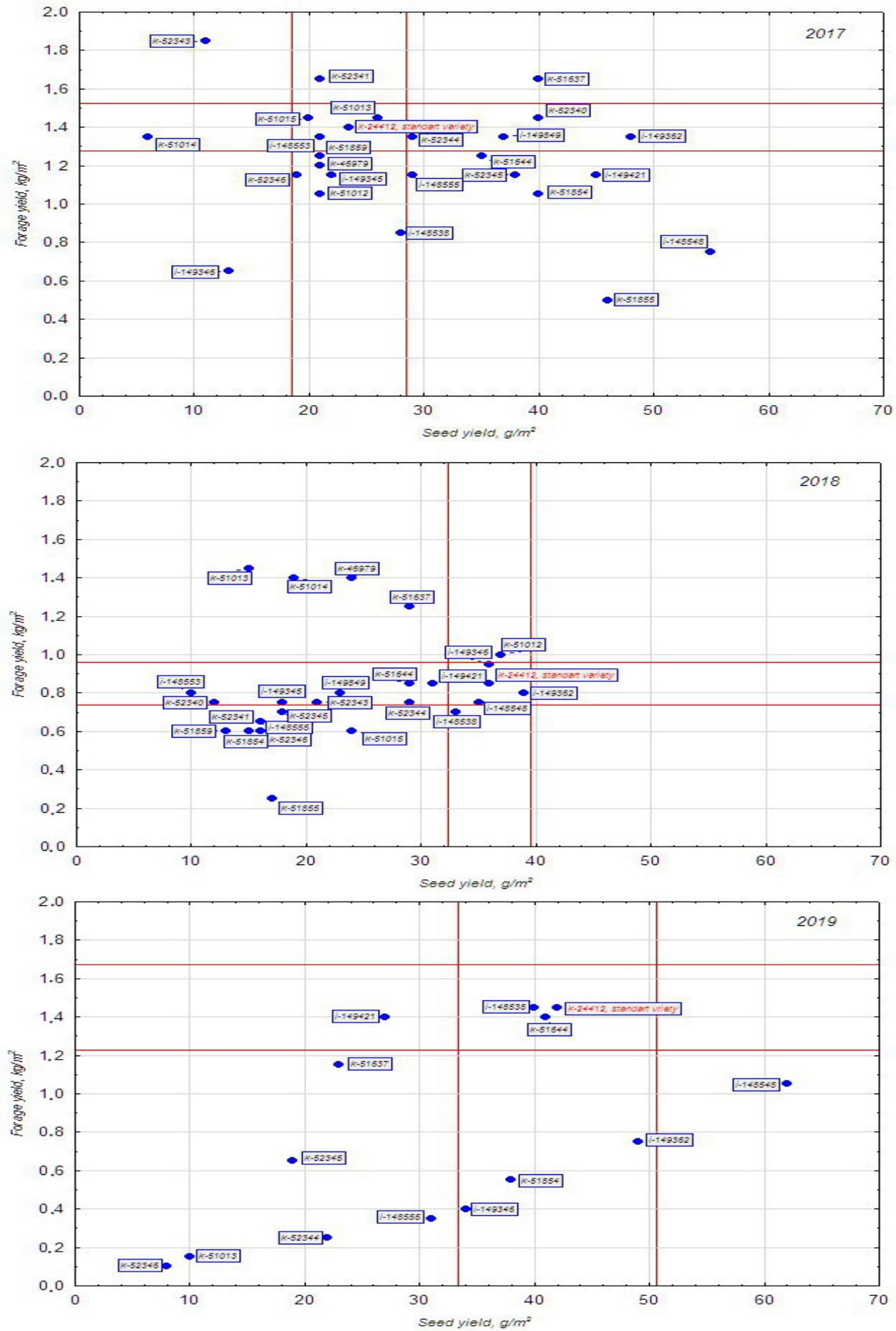

Fig. 1. Forage and seed production of the accessions of cocksfoot collection (Ekaterininskaya RS, 20172019). The red lines are the boundaries of the confidence interval of mean for the standard variety at $p$ $=0.05$. 
Thus, as a result of the study, no accessions of cocksfoot were identified that consistently exceeded the standard grade for all three years of study. Most of the accessions of the collection exceeded the standard in terms of seed productivity in 2017 , but were inferior to it in terms of the yield of green mass. In 2018, a number of accessions exceeded the standard variety in green mass, but were inferior in seed productivity. In 2019, most of the accessions were significantly inferior to the standard. The accessions collected in the North Caucasus and Tajikistan and introduced from the Mediterranean region performed well in the first year of life, but by the third year they significantly reduced all characteristics, and twelve of them fell out of crops.

\section{Conclusion}

Separate accessions are of interest for breeding according to certain characteristics. Accessions of cocksfoot from k-51015 from Portugal and k-51014 from France are interesting as a source of an economically valuable feature - high leafiness. Accession k51637 from republic Bashkortostan was distinguished by the high yield of green mass in all the years of study. It can be recommended as a source of high yield of green mass.

The accessions of cocksfoot from the Central Region of the European part of the Russian Federation (i-0149346 from Vladimir region, i-148548 from Tula region, i-0149362 from Nizhny Novgorod region) and from the mountainous regions of the Southern Urals (k-51855 and k-51637) are of the greatest interest for breeding in the Central Chernozem zone as a source of productivity.

\section{References}

1. A.A. Zhuchenko, Ecologicheskaya genetika kulturnih rasteniy kak samostoyatelnaya nauchnaya disciplina, Teoriya i praktika, (Krasnodar, Prosveschenie-Yug, 2010)

2. N. Malysheva, A. Soloveva, T. Dyubenko, N. Kovaleva, L. Malyshev, Research for Rural Development 2019. Annual 25th International Scientific Conference Proceedings, 2 (Jelgava: Latvia University of Life Sciences and Technologies, 2019)

3. I.A. Kireeva-Genenko, E.P. Novikova, A.S. Chumeikina, Uspehi sovremennogo estestvoznaniya 7 (2017)

4. Nauchno-prikladnoi spravochnik po klimatu SSSR. Kaluga, Tula, Tambov, Bryansk, Lipetsk, Orel, Kursk, Voronezh, Belgorod regions, Multiyear data, 3, 1-6(28) (1990)

5. M.E. Bookovsky, S.N. Dudnik, A.G. Shalagina, V.N. Shcetiinin, Voprosi sovremennoy nauki, 2(64) (2017)

6. N.I. Dudnik, Vestnik Tambovskogo universiteta. Seriya: Estestvennie i tekhnicheskie nauki, 7(1) (2002)

7. A. I. Ivanov, A.V. Bukhteeva, Z.P. Shutova, I.A. Tihomirova, Yu.D. Soskov, A.A. Sinyakov, E.Ya. Bazilev, Metodicheskie ukazaniya (Leningrad: VIR, 1985)

8. V.V. Inozemtsev, Korma 5 (1977) 